\section{Assessement of information resources of public libraries in Rivers state, Nigeria}

\author{
Anthonia U. Nwabueze \\ Nnamdi Azikiwe University, Awka, Nigeria
}

\section{Gideon B. Ntogo-Saghanen}

Federal College of Education (Technical) Omoku, Nigeria
Information Impact:

Journal of Information and Knowledge Management 2017, Vol. 8 (2) Pg 38 - 51 ISSN: $2141-4297$ (print) ISSN: 2360 - 994X (e-version) www.informationimpact.org

\begin{abstract}
The paper assessed information resources of public libraries in Rivers State. A survey research design was used for the study; four research questions and one hypothesis were formulated to guide the study. The population of the study comprised of 1150 public library users and librarians in Rivers State. A sample size of 220 public library users and 10 librarians were obtained through purposive sampling techniques. A structure questionnaire and a checklist were used to collect data for the study. Data obtained were analyzed using arithmetic mean and the hypothesis tested with z-test. The checklist was analyzed based on the degree to which the items are available. Findings revealed that public libraries in Rivers State provide adequate information resources for users, awareness of resources provided by public libraries in Rivers State is low, inadequate funding, high cost of information resources are some of the problems faced by public libraries in Rivers State. Some recommendations were made for improvement.
\end{abstract}

\title{
Introduction
}

The establishment of public library is based on the need to provide library resources and services to support education, research, recreation, cultural, political and information needs of the public. It is a facility set up by the government to render information service, to every member of the public irrespective of educational background, age, gender, language, religion, politics and nationality. Seavey (2003), described public library as an agency of knowledge, providing opportunities for life-long learning, independent decision making, and culture development of individuals and social groups. It is an organization established, and supported through local, regional or through some other form of community organizations.

Information resources, according to Ahiauzu, Kubo and Igben (2007), are interpreted to mean only those resources that have been acquired and processed for use. Today libraries do not only have books but also stock with variety of information resources which are in print and non-print sources. These information resources are government publications, rare books, textbooks, fictions, encyclopedias, dictionaries, geographies, maps, atlases, journals, microform, microfilm, periodicals, DVD, RAM, CD-ROM, computer, cassettes, painting, videos, floppy disk, compact disks, pamphlets, television and many more. 
Information resources are inevitable in library operations as they enable the library to fulfill its objectives of meeting the information need of users. It is the source from which people receive ideas, meaningful messages, enlightenment and directions that will help them to accomplish task, take decision and solve problems. Public library provide services for youths whose areas of interests often include adventures, sports, stories, science, fictions and other fantasies.

Public library is expected to provide a wide range of information resources in a variety of formats and in sufficient quantity to meet the need and interest of its users. Aguolu and Aguolu (2002) recommended that information material to be represented in typical public library should include; fictions and non-fictions for adults, young people and children, reference works, periodicals, newspapers and government information sources. For effective service delivery the UNESCO Public Library Standard (2000,) recommends that;

- $\quad$ An establish library services serving 100,000 population book stocks of 200,000 volumes (2 books per head).

- $\quad$ Public library should offer an adequate choice of up-to-date books and materials to meet the information need of the community.

- Public libraries should provide relevant books and materials in different indigenous languages.

- $\quad$ Each public library should have up-to-date magazines periodicals and newspapers as part of its collection.

- $\quad$ Public libraries should at least have one television for users, non-print materials in the form of CD-ROMs, DVDs, Videos and tapes

- $\quad$ Every public library should have a fixed telephone line, fax machine, a printer, scanner, photocopying machine, ICT in order to provide and communicate with users and other libraries. The role of public library is indispensable because through libraries, people can have access to vital information on government policies and programmes, information necessary for full mobilization of the people and create public awareness.

Users of public libraries have different background, while some are highly educated, many are not literate, while some are physically able, a few could be physically challenged, their ages also varies from children to senior citizens, some users are experienced and sophisticated and may need in-depth search while many may be visiting the library for the first time. Given the large disparity among the users of public libraries, it is obvious that public libraries must provide a variety of information resources in order to meet the need of various users. 
Assessment of information resources of public libraries in Rivers state, Nigeria

The philosophy underlying the establishment of public library in Rivers State is to provide library resources and services to every member of the community according to their needs and circumstances. But observation reveals that public libraries in Rivers State may not be fulfilling this objective satisfactory. Library users go into the library with their reading materials. This may be the reason, why Nwosu (2013), remarked that public library in Nigeria are not given maximum and increasing attention and this may be owing to the fact that public library is not a profit making organization, forgetting that it is the store house of knowledge and information. In view of this, the study therefore set out to; assess the information resources of Public Libraries in Rivers State.

\section{Purpose of the study}

The purpose of the study was to:

- Assess the information resources provided by public libraries in Rivers State

- $\quad$ Find out users awareness of information resources provided by public libraries in Rivers State

- To find out the information need of public library users in Rivers State

- Ascertain the problems face by public libraries with particular reference to information sources

\section{Research question}

- To what extent are information resources provided by public libraries in Rivers State?

- What is the extent of user's awareness of information resources provided by public libraries in Rivers State?

- What information resources are needed by public libraries users in Rivers State?

- What are the problems faced by public libraries with particular reference to information resources?

\section{Hypotheses}

- Rivers State public libraries do not significantly provide adequate library resources to the people of the state.

\section{Methodology}

The study is a descriptive research which employs a survey design. A survey design is necessary for this study because it specifies how data relating to a given problem will be collected and analyzed. The population of the study comprised 1150 public library users and librarians in Rivers State. The sample size comprised 220 library users and 10 librarians selected through purposive sampling techniques. Four research questions guided the study and one null hypothesis. Observation checklist was designed to record 
inventory of resources and a structured questionnaire titled "Assessment of Information Resources of Public Libraries in Rivers State (AIRPLRS) was designed for the study to collect data. Data obtained were analyzed using arithmetic mean and the hypothesis tested with $z$-test. The observation checklist was analyzed according to the degree to which the items are available in the libraries.

\section{Findings and discussion}

Data obtained for this study were analyzed and presented based on the research questions and hypotheses that guided the study. Out of 230 copies of questionnaire distributed, 227 which represents $98 \%$ return rate were duly completed, returned and were used in the analysis of this research.

Research Question 1: To what extent are information resources available in public libraries in Rivers State?

Table 1: Availability of Information Resources in Public Libraries in Rivers State

\begin{tabular}{|c|c|c|c|c|c|}
\hline Items & $\begin{array}{l}\text { Public } \\
\text { Lib. } \\
\text { Gokana }\end{array}$ & $\begin{array}{l}\text { Public } \\
\text { Lib. } \\
\text { Okrika }\end{array}$ & $\begin{array}{l}\text { Public } \\
\text { Lib. } \\
\text { Khana }\end{array}$ & $\begin{array}{l}\text { Jubilee } \\
\text { Lib. P.H }\end{array}$ & $\begin{array}{l}\text { Central } \\
\text { Lib. PH }\end{array}$ \\
\hline Text books & 6,278 & 4,273 & 3,743 & 2,322 & 16,171 \\
\hline Ref. books & 195 & 118 & 51 & 82 & 1939 \\
\hline e-journals & 81 & - & - & - & - \\
\hline Scanners & - & - & - & - & - \\
\hline Printers & 4 & - & - & - & - \\
\hline Fiction & 132 & 213 & 162 & 140 & 741 \\
\hline e-books & 120 & - & - & - & - \\
\hline CD-ROM & 10 & - & - & - & - \\
\hline Internets & 1 & - & - & - & - \\
\hline $\begin{array}{l}\text { Gov. } \\
\text { Publications }\end{array}$ & 49 & 33 & 52 & 93 & 564 \\
\hline Computers & 122 & - & - & - & - \\
\hline $\begin{array}{l}\text { Photocopying } \\
\text { machines }\end{array}$ & - & - & - & - & 3 \\
\hline Periodicals & 25 & 48 & 21 & 10 & 653 \\
\hline Projectors & - & - & - & - & - \\
\hline Children books & 298 & 211 & 142 & 198 & 2,321 \\
\hline Satellites TV & - & - & - & - & - \\
\hline Int'1 & - & 21 & - & - & 83 \\
\hline Publications & & & & & \\
\hline T.V Sets & - & - & - & - & - \\
\hline DVD & - & - & - & - & - \\
\hline
\end{tabular}




\begin{tabular}{llllll} 
Microform & - & - & - & - & - \\
Braille & - & - & - & - & 2 \\
Speakers & - & - & - & - & - \\
Fax Machines & - & - & - & - & \\
OPAC & - & - & - & - & - \\
Microfiche & - & - & - & - & - \\
Unit Total & $\mathbf{7 , 3 0 5}$ & $\mathbf{4 , 9 1 7}$ & $\mathbf{4 , 1 7 1}$ & $\mathbf{2 , 8 5 1}$ & $\mathbf{2 2 , 4 7 7}$ \\
& \multicolumn{5}{c}{ Overall total 41,722 }
\end{tabular}

The observation checklist shows that all the libraries investigated have textbooks, reference sources, fictions, government publications, periodicals and children books.

At the Central Library Port Harcourt, nine types of information resources out of twenty five types checked were found. The information resources found were textbooks, reference sources, fictions, government publications, photocopying machines, periodicals, children books, international publications and braille. All the information resources found in the central library Port Harcourt are twenty two thousand four hundred and seventy seven $(22,477)$.

At Jubilee Library D-Line in Port Harcourt, seven types of information resources out of twenty five checked were found. These include textbooks, reference materials, fictions, government publications, periodicals, children books and international publications. The numbers of information resources found were two thousand eight hundred and fifty one $(2,851)$.

At the public library in Khana Local Government Area, six types of information resources out of twenty five checked were found. The information resources found were children books, periodicals, government publications, novels, reference sources and textbooks. All the information sources found in this library were four thousand one hundred and seventy one $(4,171)$.

At Okrika public library seven types of information resources out of twenty five checked were found. The information resources found in this library include fictions, international publications, children books, periodicals, textbooks, and reference materials. All the resources found in this library were four thousand nine hundred and seventeen $(4,917)$.

At Gokana public library, twelve types of information resources were found out of twenty five checked. The information resources found in this library were photocopying machine, computers, periodicals, children books, government publications, Internet, CDROM, e-books, fictions, printers, reference sources, textbooks and e-journals. All the information resources found were seven thousand three hundred and five $(7,305)$.

The finding show that information resources available in public libraries in Rivers State are predominantly traditional print sources such as textbooks, reference materials, 
fictions, government publications, periodicals sources, children books and international publications.

The observation checklist shows that only public library in Gokana has Information and Communication Technology (ICT) resources such as C.D-ROM, e-books, e-journal, Internet and printers. The total of the information resources in the five public libraries is forty one thousand seven hundred and twenty one $(41,722)$ in number.

\section{Research question 2: To what extent is the public aware of the information resources provided by public libraries in Rivers State?}

Table2: Mean Scores on Extent of Awareness of the Information Resources Provided by Public Library

\begin{tabular}{lll}
\multicolumn{1}{c}{ Items } & Mean & Decision \\
\hline 1. General dictionaries & 2.75 & High extent \\
2. Biographies & 2.73 & High extent \\
3. Children books & 2.54 & High extent \\
4. Fictions & 2.51 & High extent \\
5.Textbooks & 2.50 & High extent \\
6.Newspapers & 2.35 & Low extent \\
7.Directories & 2.05 & Low extent \\
8. Specialized dictionaries & 2.00 & Low extent \\
9. Almanacs & 1.98 & Low extent \\
10.Recreational materials & 1.97 & Low extent \\
11. Journals & 1.96 & Low extent \\
12. General encyclopedia & 1.93 & Low extent \\
13. Indexes and abstracts & 1.92 & Low extent \\
14. Government Publications & 1.88 & Low extent \\
15. Bibliographies & 1.85 & Low extent \\
16. Yearbooks & 1.75 & Low extent \\
17. Specialized encyclopedia & 1.73 & Low extent \\
18. Reports & 1.72 & Low extent \\
19. Travel guides & 1.64 & Low extents \\
20. Internet facilities & 1.60 & Low extent \\
21. Int'l org. publications & 1.43 & Low extent \\
22. Non-book materials & 1.38 & Low extent \\
23. Braille & 1.16 & Low extent
\end{tabular}

The analysis in Table 2 shows that the extent of public awareness of the information 
resources provided by public library is low. The item by item analysis shows that out of the 23 items of information resources provided by public library, the extent of public awareness on 18 of the items is low; their mean ranges from 1.16 to 2.35. Just five items has a high awareness.

\section{Research question 3: What information resources are needed by library users in Rivers State?}

Table 3: Mean Scores on Information resources needed by Public Library users in Rivers State

\begin{tabular}{llcc} 
& Items & Mean & Decision \\
\hline 1. $\quad$ Employment & 3.85 & High extent \\
2. $\quad$ Oil spillage & 3.66 & High extent \\
3. $\quad$ Fish production & 3.40 & High extent \\
4. $\quad$ Crime reports & 3.39 & High extent \\
5. $\quad$ Education & 3.35 & High extent \\
6. $\quad$ Social activities & 3.32 & High extent \\
7. $\quad$ Health & 3.30 & High extent \\
8. $\quad$ Environment & 3.30 & High extent \\
9. $\quad$ Politics & 3.29 & High extent \\
10. Disease control & 3.16 & High extent \\
11 $\quad$ Security & 3.13 & High extent \\
12. $\quad$ Sports & 3.10 & High extent \\
13. Disease control & 3.04 & High extent \\
14. Business & 2.65 & High extent \\
15. Current affairs & 2.59 & High extent \\
16. Govt. programme & 2.59 & High extent \\
17. Human right & 2.57 & High extent \\
18. Religion & 2.55 & High extent \\
19. Agriculture & 2.50 & High extent \\
20. Food storage & 2.30 & Lowextent \\
21.Entertainment & 2.24 & Low extent \\
22. Historical sources & 2.23 & Low extent \\
23. Flood prevention & 2.20 & Low extent \\
24. Terrorism & 2.14 & Low extent \\
25. Economy & 2.10 & Low extent \\
26. Pest control & 2.10 & Low extent \\
27. Fertilizer application & 2.01 & Low extent \\
28. Customs \& tradition & 1.43 & Low extent \\
\hline
\end{tabular}

As shown by the analysis in Table 3, indicate that public library users in Rivers State 
Assessment of information resources of public libraries in Rivers state,

Nigeria

need different sources of information. Item by item analysis shows that out of the 27 items on information sources 19 items are of interest to the library users. Their mean ranges from 2.50 to 3.8

\section{Research question 4: What are the problems faced by public libraries in River State while providing information resources for users}

Table 4: Mean Scores on the Problems faced by Public Libraries in Rivers State while Providing Information Resources and Services

Items

1. High cost of library resources

2. Inadequate library resources

3. Inadequate ICT resources

4. Inadequate fund

5. Lack of selection tools

6. Mutilation of library resources

7. Obsolete classification tools

8. Theft of library resources mean

3.90

3.70

3.70

3.30

2.10

2.10

2.00

2.00 decision

High extent

High extent

High extent

High extent

Low extent

Low extent

Low extent

Low extent

From the mean of responses in Table 4 above, 4 items out of 8 listed which are inadequate library resources, inadequate fund, high cost of library resources, inadequate ICT related resources are accepted as the problems faced by public libraries in Rivers State while providing information resources for users. Their mean ranges from 3.30 to 3.90 .

\section{Hypothesis testing:}

Hypothesis 1: Rivers State public libraries do not significantly provide adequate library resources for users.

Table 5: Test Analysis on Provision of Adequate Information Resources for Users

\begin{tabular}{llllllll}
\hline & Items & mean & SD & df & z-cal & z-crit & \\
\hline 1. & Textbooks & 2.51 & 1.39 & 219 & 26.84 & 1.96 & \\
2. & Journals & 1.97 & 1.05 & 219 & 27.72 & 1.96 & \\
3. & Newspapers & 2.35 & 1.43 & 219 & 24.36 & 1.96 & \\
4. & Non-books & 1.38 & .60 & 219 & 33.92 & 1.96 & \\
5. & Int'l org. publ. 1.43 & .65 & 219 & 32.77 & 1.96 & \\
6. & Braille & .16 & .46 & 219 & 37.61 & 1.96 & \\
7. & Children books & 1.89 & 1.23 & 219 & 22.86 & 1.96 & \\
8. & Internets & 1.60 & .82 & 219 & 29.08 & 1.96 & \\
& & & & & & & 45
\end{tabular}


Assessment of information resources of public libraries in Rivers state, Nigeria

$\begin{array}{lccccc}\text { 9. Govt publ. } & 1.89 & .94 & 219 & 29.71 & 1.96 \\ \text { 10. Fictions } & 1.76 & .85 & 219 & 30.63 & 1.96 \\ \text { 11. Yearbooks } & 1.76 & .81 & 219 & 32.37 & 1.96 \\ \text { 12. Reports } & 1.72 & .75 & 219 & 34.22 & 1.96 \\ \text { 13. Recreational sources } 1.97 & .70 & 219 & 42.09 & 1.96 \\ \text { 14. Travel guides } & 1.64 & .68 & 219 & 35.55 & 1.96 \\ \text { 15. Indexes \& abst. } & 1.93 & .95 & 219 & 30.15 & 1.96 \\ \text { 16. Bibliographies } & 1.85 & 1.00219 & 27.48 & 1.96 \\ \text { 17. Gen. encycl. } & 1.93 & 1.08 & 219 & 26.50 & 1.96 \\ \text { 18. Subj. Encycl. } & 1.74 & .94 & 219 & 27.31 & 1.96 \\ \text { 19. Biographies } & 1.73 & 1.00 & 219 & 25.79 & 1.96 \\ \text { 20. Gen. dictionaries } & 1.75 & .93 & 219 & 27.77 & 1.96 \\ \text { 21. Subj dictionaries } & 2.01 & .83 & 219 & 35.77 & 1.96 \\ \text { 22. Directories } & 2.06 & .96 & 219 & 31.78 & 1.96 \\ \text { 23. Almanacs } & 1.98 & .94 & 219 & 31.40 & 1.96\end{array}$

The hypothesis 1 sample z-test analysis presented in Table 4 shows that Rivers State public libraries provide adequate library resources for users as all the observed mean ratings were up to the test value of (2.50) and above, this was shown by the fact that all the calculated z-values for all the items were greater than the critical z-value of 1.96. This is an indication that the respondents mean ratings on all these items were significantly up to and above the scale average of 2.50. This shows that the respondents were of the view that Rivers State public libraries provide adequate library resources for users. Hence hypothesis 1 is therefore rejected that public libraries in Rivers State do not significantly provide adequate library resources.

\section{Major Findings}

The major findings of this study revealed that:

$>$ Public libraries in Rivers State provide adequate information resources. The finding is based on the UNESCO Standard which recommends a media book stock of 200,000 volumes for a population of 100,000 users (2 books per head). Public libraries in Rivers State, serving a population of 1150 users have a book stock of 41,722 information resources which is approximately (36 books per head). Findings also revealed that information resources found are mostly in traditional book formats, modern information resources were not available in the public libraries investigated except in Gokana public library.

$>$ Users' awareness of the information resources provided by public libraries in Rivers State is low. From the available information resources in these libraries, users are aware of only five types of information resources.

$>$ The study found that public library users' in Rivers State need various 
Assessment of information resources of public libraries in Rivers state, Nigeria

information resources on education, health, employment, security, environment, crime reports, social activities, religion, politics, agriculture, sports, government programmes, current affairs, fish production, human right, business, oil spillage, and disease control.

$>$ The identified problems hindering public libraries while providing information resources to the community are high cost of Library resources, lack of ICT facilities and insufficient fund.

Finally, test of the hypothesis indicate that public libraries in Rivers State significantly provide adequate information resources for users.

\section{Conclusion and recommendations}

From data analysis on findings of this study, it can be concluded that; the overall provision of information resources in [public libraries in Rivers State is adequate as it meet the recommendations of the UNESCO public library standard, though information resources found may not satisfy the sophisticated information need of public library users as a result of inadequate modern information resources. User's low awareness of information sources provided by public libraries in Rivers State may be responsible for low patronage. Library users need varying degrees of information to be able to function well in the society but are deprived access to these information sources in the library. The numerous problems that hinder public libraries while providing information resources for users include inadequate library resources, high cost of information resources, inadequate funding and lack of ICT related resources.

It is in light of the foregoing that the following recommendations are made.

1. The Rivers State Government should provide adequate fund for acquisition of upto-date information resources, while the Rivers State Library Board, should enter into partnership with the State Government, Local Government and the Multinational Oil Companies operating in the state and institute a yearly library development fund raising campaign for public libraries.

2. The public libraries should create awareness among users on various information resources available, through user-education, orientation, regular publication of accession list and provision of error free catalogues, library guides, exhibitions to acquaint users' with various available resources.

3. Public libraries in Rivers State, should be computerized, networked and be involved in inter-library loan, collaboration, resource sharing and provision of Internet services to enable users have access to unlimited information resources in databases.

4. The State government should from time-time review public library allocations to enable them meet the constant changes in the cost of information resources.

Information Impact | Journal of Information and Knowledge Management 
Assessment of information resources of public libraries in Rivers state,

Nigeria

\section{References}

Abdulkarim, M (2010). Improving public libraries in Nigeria. Heartland Journals of Library and Information science, 2 (1 \& 2), 3 - 10

Abolaji J.A. (2009). How library contribute to communities and society. Ozean Journal of Social Sciences, 2 (3), 15-23

Adebayo, M. (2012). Information needs and seeking behaviours of school Principals: Challenges for Libraries. Middle Belt Journal of Library and Information Science, 10 (1), 165-178

Adomi, E.E. (2009). Library and information resources. Benin: Ethiope Publishing Company.

Aguolu, C.C. \& Aguolu I.E. (2002). Libraries and information management in Nigeria. Maiduguri: Nigeria Uniform Servces.

Ahiauzu, B. (2008). Information seeking of research scientists in era of globalization of library and information services in Nigeria: A case study of Rivers State University of Science and Technology. Port Harcourt Emerald UK Library Management, 2 (6 \& 7) 27-33

Ahiauzu, B. Akobo, D. I. \& Igben, M. J (2007). Fundamentals of library Practices. Port Harcourt: David Stones Publishers.

Aina, L.O. (2004). Coping with challenges of libraries and information Services Delivery and need for institutionalized professional development. Paper Presented at the $42 \mathrm{NLA}$

National Conference/AGM Akure, 20-25 June.

Anwar, M.A. Al- Asari H. \& Abdulah (2004). Information seeking behavior of Kuwiti Journalist. Libri, 54 (4), 228-236

Bello, A.S. (2001). Library user malpractice: A case study of the Ibadan Polytechnic Library. Nigerian Libraries. 35 (1), 23-32 
Assessment of information resources of public libraries in Rivers state,

Nigeria

Bruce, C.S. (2002). Information library as a catalyst for educational change: A back ground paper of the U.S. national commission on libraries and information sciences from http:/www/nclis.gov/linb.inter/intotincom and meet/access on 6/7/2005.

Edem, U.S. (2003). Information needs and information seeking behaviour pattern of journalists in Nigeria. African Journal of Library Archives and Information Science, 3 (2), 167-174

Egbuma, S \& Eyisi G. (2011). Community based library and information services in Anambra State. NLA $49^{\text {th }}$ National Conference and Annual general meeting Awka, July $10^{\text {th }}-15^{\text {th }}$

Emogoroh, D. (2005). Public library and nation building: The Nigerian experience. Library management, 26 (3), 23-19

Fayose, O. (2000). Library resources and their roles in education. Ibadan: Unipress Ibadan Centre for External Studies.

Gbadamasi, B.O. (2004). Medical director's information requirements seeking strategies and utilization in government hospitals in Oyo State. Middle Belt Journal of library and information science, 4 (1), 20-23

Igbeka, J.U. \& Atinimo M.I. (2002). Informatin seeking behavior and information utilization of agricultural engineers based on their different places of work. Nigerian Libraries, 36 (10), 9-22

Ifidon, S.E. (2006). Modern theory and practice of library collection development. Benin City: Justice. Jeco Press Ltd.

Imeremba D.U. (2011). Routines libraries: A synthesis of technical and readers services operation Enugu: Kenndy Publishers.

Mutula, S. M. (2000). I T development in Eastern and Southern Africa: Implication of public libraries. HiTech, 18 (4), 183-200

Nwegbu, M.U. (2004). Marketing library services, current practices, 
Assessment of information resources of public libraries in Rivers state,

Nigeria

problems and prospects: a case of Nnamdi Azikiwe library, university of Nigeria Nsukka Coal City Library, 1(1), 88-96

Nwosu, C. (2000). A textbook in use of the library for higher

Education. Owerri: Springfield Publishers.

Nwosu, I. G. (2013). Effect on access and use of library resources in South Eastern Nigeria: A case study of Abia, and Rivers State public libraries. Journal of Library and Information Science and Technology, 2 (3 \& 4), 83-99

Ogurunbi, L.O. (2005). Toward the provision of efficient library services for the disabled in Nigeria. Borno Library, Archival and Information service Journal, 8 (2), 198-206

Omulayole, O.O. (2004). Nigerian libraries and information service centre. The challenges of socio-economic/technological development of the $21^{\text {st }}$ Century. Niger Biblius, 15(1), 1-9

RAO, S. S. (2005). Electronic books: their integration into the Electronics Library. Library and Information Science Centres, 6 (2), 70-79

Rehman S. and Ramzy V. (2004). Awareness and use of electronic information resources at the Institute of Science and Technology Centre Kuwait. Library Review 53(3

Rivers State of Nigeria (1971). Library Board Edict No 23 April. Port Harcourt: Government Press.

Saka, K.A. (2006). Information needs of medical and health practitioners in three local government areas of Niger State. Zaria Journal of Librarianship, 9 (1), 1-14

Stipanov, J. (2005). Knowledge society and public libraries. Online Publication Retrieved from http/www/Naple infi/supertar/stipone pdf

Tathagata, R. (2010) Repositioning public library in Nigeria Online publication Retrieved from http/mzweekly.com/maslows 
Assessment of information resources of public libraries in Rivers state,

Nigeria

hierachy.

Tunde, O.K. \& Zainab, H. (2012) The relevance of libraries in the achievement of vision 20:20:20 objectives in Nigeria:

challenges and prospects. Middlebelt Journal of Library and

Information Science, 10 (1), 206-214

UNESCO (2001). Guidelines for public library development.

USA: IFLA Publication.

UNESCO (2000). Public library manifesto retrieved from hpp//ifla.org/58/Unesco/eng.

World Book Encyclopedia (Vol. 12), (2001). Chicago: World Book Inc.

A.U. Nwabueze $(\mathrm{PhD})$ is a lecturer the Department of Library and Information Science, Nnamdi Azikiwe University, Awka, Anambra State, Nigeria

G. B. Ntogo-Saghanen is librarian at the Federal College of Education (Technical), Omoku, Rivers State, Nigeria 